\title{
AWARENESS OF ORGANIC PRODUCTS IN DNEPROPETROVSK REGION, UKRAINE
}

\author{
Roman BEZUS ${ }^{*}$, Iuliia AMELINA ${ }^{2}$
}

\begin{abstract}
Address:
${ }^{1}$ Dnepropetrovsk State University of Agriculture and Economics, Accounting and Finance faculty, Department of Finance, 25 Voroshilov str., 49600 Dnepropetrovsk, Ukraine, phone:+380979450457

2 Dnepropetrovsk State University of Agriculture and Economics, Accounting and Finance faculty, Department of Accounting and Auditing, 25 Voroshilov str., 49600 Dnepropetrovsk, Ukraine

*Corresponding author, e-mail:9450457@ukr.net
\end{abstract}

\begin{abstract}
In the article we assessed consumers’ awareness level of organic products in Dnepropetrovsk region, Ukraine, in 2012. Based on 850 consumers' responses we found that level of awareness of organics in Dnepropetrovsk region was high enough and exceeded the awareness level of citizens in France 2011. The most informed group of organic products were consumers aged 35 to 39 . Almost $83 \%$ respondents of this age group were willing to buy organic products. Special attention we paid to potential distribution channels for organic products, among which the largest are supermarkets, specialty stores and food markets. We found, that increase of public awareness level of organic products in Dnepropetrovsk region affects positively consumers' willingness to pay a premium for these products.
\end{abstract}

Keywords: organic products, awareness, distribution channels, willingness to pay, Ukraine JEL: M31, Q 01, Q11, Q13, R15

\section{INTRODUCTION}

Despite significant level of information processing systems, information has been changing nature of the society. The information is shaped under public opinion and scientific knowledge influence. Information about new products should promote a willingness to buy them, especially taking into account their advantages for consumers. To gain a competitive advantage, agricultural enterprises oriented to concentric diversification, focus on a new type of efficient production taking into account endogenous and exogenous factors. Awareness of potential users about the new product belongs to requirements of successful diversification.

There is a lack of comprehensive studies of public awareness of organic products consumption in Ukraine. This topic was analysed partially by Artysh (2006), Mylovanov, (2009), Berlach, (2010), Yatsenko and Zavadska (2010), Pidlisnyuk and Stefanovska (2008), Tchaika (2011) based on data from selected regions of Ukraine, e.g. Kyiv, Zhytomyr, Mykolayiv, Lviv, Cherkasy, Vinnytsia, Khmelnytsky, Chernigiv regions.

The objective of our study was to assess a level of residents' awareness of organic products, level of willingness to buy them and identify motivation for readiness to pay a premium for organic food in the Dnepropetrovsk region, Ukraine. Dnepropetrovsk is considered as one of the leading regions of organic products consumption in Ukraine.

\section{MATERIAL AND METHODS}

We conducted survey to collect primary sociological information. Empirical data collected from self-rating questionnaire we processed by structural, factor and cluster analysis, using statistical package SPSS.

The survey took place in Dnepropetrovsk region villages, towns, and cities (with overall population over 3 million), namely in Dneprodzerzhinsk and the regional centre - Dnepropetrovsk in 2012. Total number of respondents (quota sampling) was 850. We used 95\% confidence level and confidence interval.

To assess awareness level of organic products and ready to pay a premium for organic products, we calculated square of the Euclidean distance (Eq.1).

$\mathrm{d}^{2}=\sum_{\mathrm{l}=1}^{\mathrm{m}}\left(\mathrm{x}_{\mathrm{i}}-\mathrm{y}_{\mathrm{i}}\right)^{2}$

Where: $d^{2}$ - distance between objects $x$ and $y$; $x_{i}$ - value of the $i^{-}{ }^{\text {th }}$ characteristic of object $x$; $y_{i}$ - value of the $i^{- \text {th }}$ characteristic of object $y$.

To identify groups of the most similar values of awareness level we used the nearest neighbour method, where the distance is equal to the distance between objects and classes (Eq. 2).

$p_{\min }\left(K_{i}, K_{j}\right)=\min _{x \in K_{i}, y \in K_{j}} p(x, y)$

where, $p_{\min }\left(K_{i}, K_{j}\right)$ - minimum distance from $K_{i}$ to $K_{j}$ cluster.

We use factor analysis and principal components method, in order to reduce the number of variables (data 
reduction) and determine the structure of relationship between variables. Factor analysis is used as a method of data reduction or a method of classification. This approach allows us to reduce dimension of the sample size. The information included in the entire data set is preserved. The following assumptions of applying factor analysis need to be met: all variables are quantitative; a sample must be homogeneous; output variables are distributed symmetrically; analysis is carried out by correlated variables (Shumetov, 1999).

\section{RESULTS AND DISCUSSION}

Organic food market in Ukraine is influenced by internal and external factors. Internal factors are stipulated by the growing demand for safe and healthy food as a result of living standards improvement. External factors are caused by the dynamic growth of the organic products global market and the international community interest in Ukraine as potentially powerful producer of such products.

In 2013 more than 70 enterprises in Ukraine used the principle of organic farming (Ministry of Agrarian Policy and Food of Ukraine, 2013). Organic products consisted of mainly cereals, pulses and oilseeds. About $80-90 \%$ of organic products were exported to the EU (Italy, Germany, Netherlands, Switzerland, and France), North America (U.S. and Canada), Russia, Israel and Japan. Only $5-10 \%$ of the remaining part of the products certified by international standards, sold on domestic market, is labelled as "organic product". It should be noted that there is lack of accurate data for the organic products, due to the absence of official statistics and customs statistics. Customs declarations do not distinguish organic and conventional produce.

Although organic products market in Ukraine exhibited high growth rates, its share reached in 2012 only $0.19 \%$ (Lupenko, 2013). Estimated potential capacity of organic products market in Ukraine (expressed as a value of organic products consumption) (Fig. 1) is comparable to actual organic products market capacity of France. With retail sale of organic products (3.7 bn. EUR) in 2013, France belongs to one of the leading countries of organic products consumption, following USA (21 bn. EUR) and Germany (6.6 bn. EUR) (Organic market report, 2013). GDP per capita in France however, is 10 times higher than in Ukraine (for citizens aged 25 years and above). To achieve the potential market capacity of organic products in Ukraine, it is necessary to improve the economic situation in the country and to provide consumers with information about benefits of organic products consumption.

In Dnepropetrovsk region study respondents were asked to rate their awareness of organic products on ten points scale. $50.3 \%$ of respondents rated their awareness level as above average. $12 \%$ of respondents believe that they are well-informed about what is organic food as their awareness was rated by 10 points. $5.9 \%$ of respondents assessed their awareness by 9 points, $8.2 \%$ by 8 points, $10.6 \%$ by 7 points, $13.6 \%$ by in 6 points, $16.5 \%$ by 5 points, $9.9 \%$ by 4 points, $9.3 \%$ by 3 points,
$4.6 \%$ by 2 points. $6.1 \%$ of respondents were informed insufficiently (1 point) (Table 1).

Agence Bio - CSA (2011) found that 9\% of respondents in France consider themselves as very wellinformed about organic products (Fig. 2). We compared the survey results of awareness in Dnepropetrovsk region and those found for France. The share of Dnepropetrovsk region respondents who claim to be very knowledgeable on organic products was in 2012 higher by $8.9 \%$ than the relevant one in France. This indicates that consumers of Dnepropetrovsk region consider their awareness of organic products to be sufficiently high and comparable to those in the Western Europe.

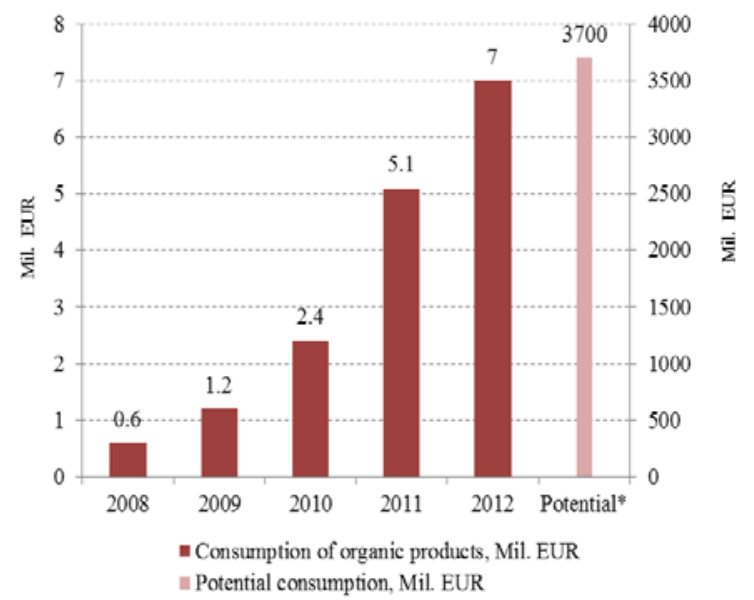

Figure 1. Consumption of organic products in Ukraine, mil. EUR, 2008-2012

Source: Lupenko (2013); Federation of Organic Movement of Ukraine (2014)

Respondents' awareness of organic products in Dnepropetrovsk region increased with their age. Half of the respondents aged over 75 years assessed their knowledge on the subject by 10 points. One quarter of respondents aged 45-49, aged 60-64 and aged 70-74 rated their knowledge by 10 points. The same rating was done by $20 \%$ of respondents aged $65-69$.

Among those who rated their knowledge as very good or good enough, the largest share were aged 35-39, $60-64$ and $45-49$ (62.7\%, 59.1\% and 55.3\% respectively). Interesting is the fact that respondents of the age group 70 and older never answered "not well-informed". Among those who indicated the lowest level of awareness of organic products, most respondents were from the following age groups: 65-69 (16.7\%), 16-18 and 19-21 (15.4\%), 45-49 (14.89\%) (Fig.3).

The majority of respondents with the highest level of awareness gained secondary education (14.4\%), higher education (12.6\%) and incomplete higher education (11.6\%). Prevailing number of respondents with the lowest level of awareness of organic products had not completed their secondary education (12.5\%).

By answering one of the key questions "Do you wish to buy organic products?" almost $83 \%$ of respondents demonstrated their readiness to buy these products. This confirms that the segment of potential consumers of organic products in the Dnepropetrovsk region has already been formed. 
Table 1. The structure of the respondents' awareness of what organic products is on ten points scale

\begin{tabular}{llcccccccccc}
\hline Answer & No answer & "1" & "2" & "3" & "4" & "5" & "6" & "7" & "8" & "9" & "10" \\
\% of answers & 3.3 & 6.1 & 4.6 & 9.3 & 9.9 & 16.5 & 13.6 & 10.6 & 8.2 & 5.9 & 12 \\
\hline Source: own research & &
\end{tabular}

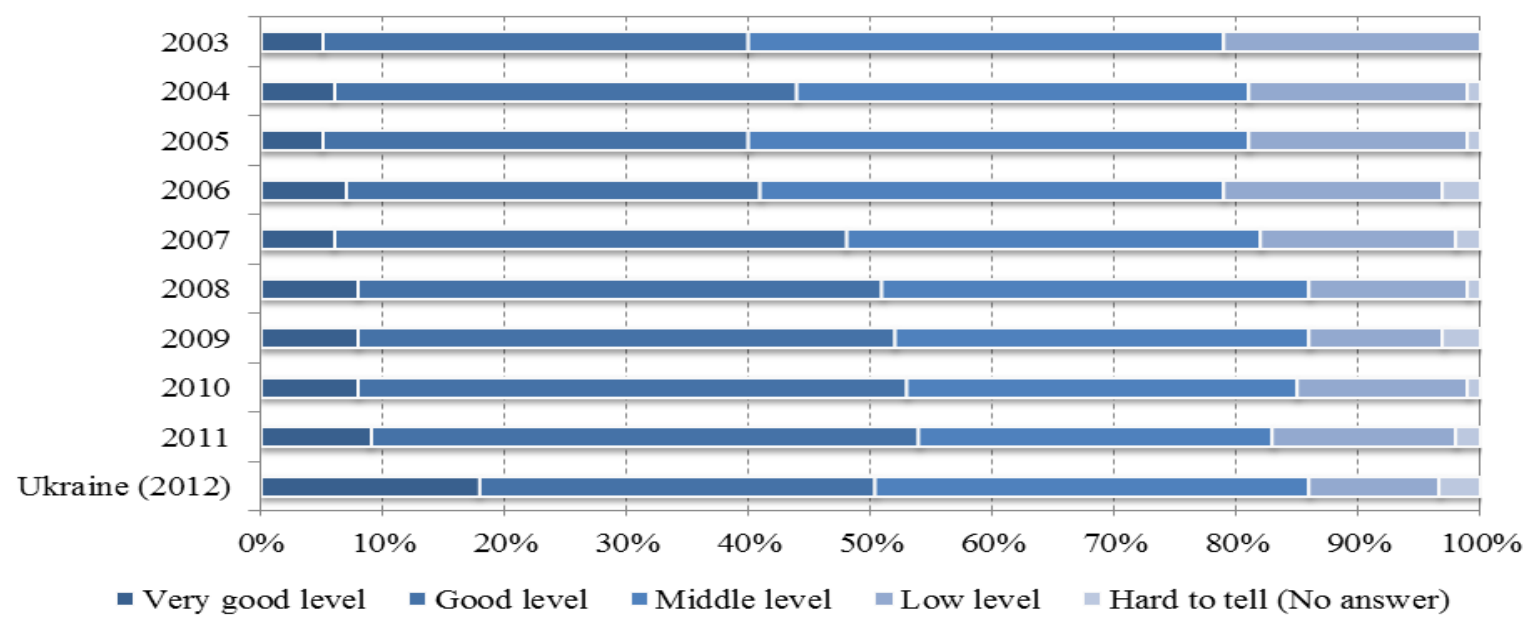

Figure 2. Trends in public awareness of organic products in France, (2003-2011) and the survey results in Dnepropetrovsk region (2012)

Source: Own research

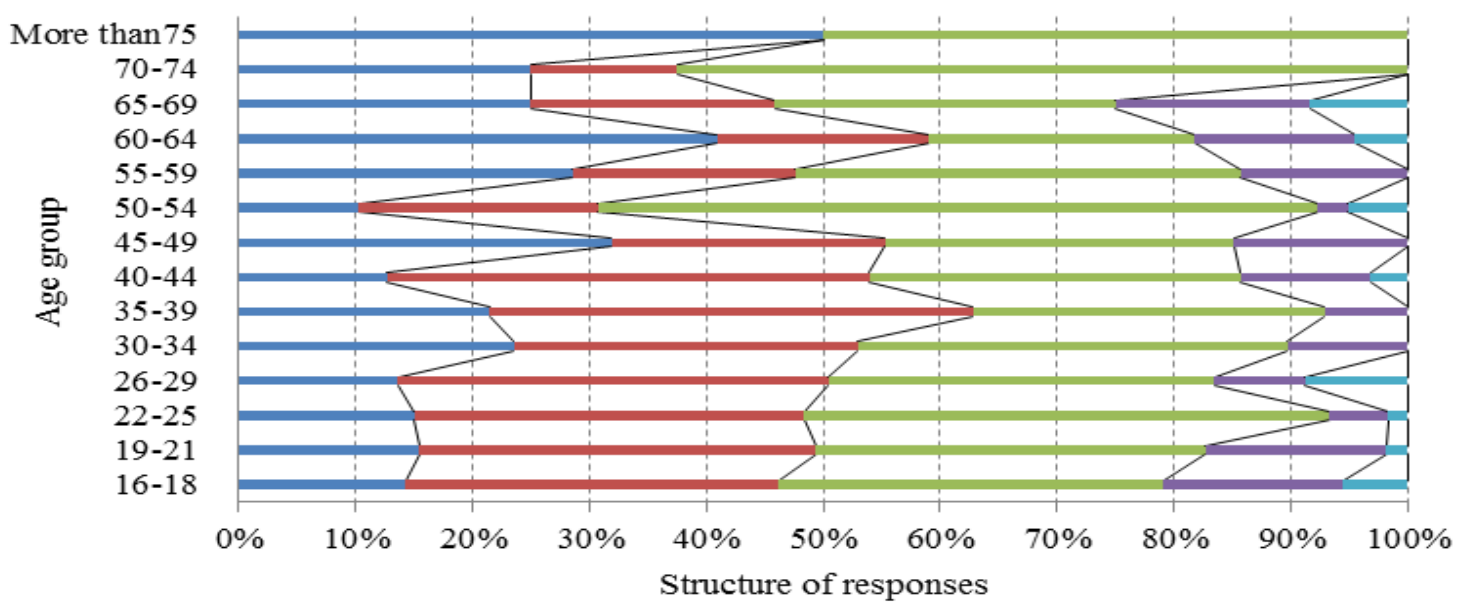

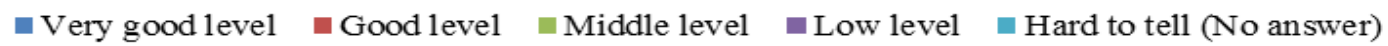

Figure 3. Responses to questions about awareness of organic products according to age groups, Dnepropetrovsk region, 2012

Source: own research

The main factors affecting the willingness of respondents in Dnepropetrovsk region to buy organic products are their willingness: to eat "worthwhile food" (55\%), to provide their children and grandchildren with organic produce (12\%), to experience new tastes (9\%) to preserve the environment (6\%). 15\% of respondents don't tend to buy organic products as they are fully satisfied with "traditional" foodstuff (Tab.2).
The French respondents indicated the following reasons of consumption of organic products (Agence Bio - CSA, 2011):

- Health and safety: "to preserve one's own health" (93\%), "for their own safety, I'm sure that these products are safe" (90\%);

- Altruistic approach: "saving the environment" (90\%), "care about the protection of animals" (77\%) and ethical reasons (70\%); 
- Taste: has always been and stays a highlight of organic products (89\%) (Fig.4).

Respondents of Dnepropetrovsk region similarly to the respondents in France prefer organic products primarily as they carry about their own and their family health.

The share of respondents willing to buy organic products in the Dnepropetrovsk region slightly decreases as their monthly income per family member increases. For example, $85.6 \%$ of respondents with monthly income up to $1,000 \mathrm{UAH}$ per family member and $70.4 \%$ of respondents with monthly incomes of more than 5001 UAH expressed their willingness to buy organic products.

Table 2. Reasons of respondents' willingness to buy or not to buy organic products in Dnepropetrovsk region, 2012.

\begin{tabular}{ll}
\hline Answer & \\
\hline No answer & 2.5 \\
Yes, because I want to eat healthy & 55.2 \\
Yes, because I want to have new food experience & 8.7 \\
Yes, but only for children or grandchildren & 11.5 \\
Yes, because I want to save the nature & 6.2 \\
Yes, else & 0.7 \\
No, I'm satisfied with "traditional" products & 14.7 \\
No, else & 0.5 \\
\hline
\end{tabular}

Source: own research

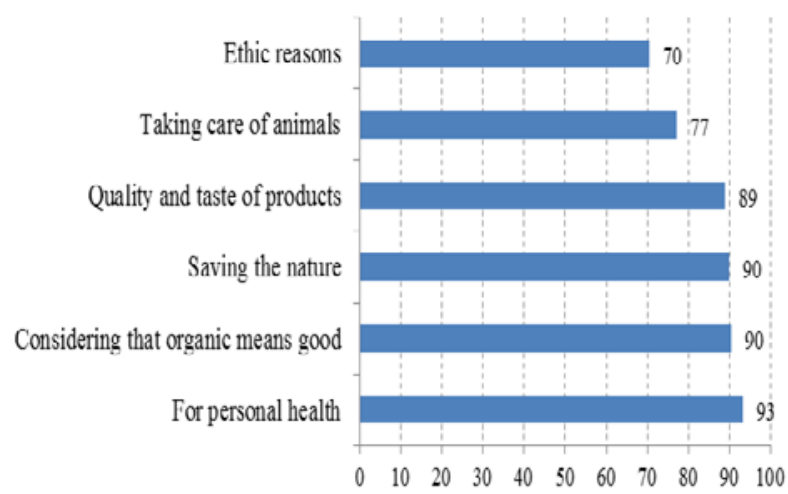

Figure 4. Structure of reasons (\%) influencing the respondents' willingness to buy organic products in France, 2011.

Source: Agence Bio - CSA (2011)

In responses to question "Where would you like to buy organic products?" $48 \%$ of respondents indicated conventional food stores (supermarkets); 21\% specialized stores for organic products; $14 \%$ farmers markets; $5 \%$ preferred to buy products directly from the producer (on a farm); $2 \%$ from online stores (home delivery); $6 \%$ were undecided; $4 \%$ of users didn't answer at all (Table 3).

According to Agence Bio - CSA (2011), 65\% of the respondents in France were buying organic products in supermarkets and hypermarkets, $43 \%$ at the market, $31 \%$ in specialized stores, $57 \%$ directly from the producers (Fig.5).
The majority of residents of the Dnepropetrovsk region were ready to pay a premium for organic products. $19.1 \%$ of respondents were not ready to pay a premium and about $13 \%$ did not answer. There were different levels of readiness to pay a premium for organic products relative conventional products for organic products according to product groups (Table 4).

We found that willingness of respondents in the Dnepropetrovsk region to buy organic products decrease by $31 \%$ with increase of a premium for these products. Respondents' readiness to pay up to $10 \%$ of premium for organic products dominates. Relatively high share of respondents are ready to pay a premium $11-20 \%$ for such products. The number of respondents who are willing to buy organic products relative conventional products by $11-20 \%$ is twice less than those who are willing to pay a premium up to $10 \%$.

Table 3. The answers to the question "Where would you like to buy organic produce?", Dnepropetrovsk region, 2012

\begin{tabular}{lc}
\hline Sales location & \% of answers \\
\hline Regular food shops & 47.6 \\
Special organic shops & 20.8 \\
Farmers market & 14.6 \\
At the farm & 4.8 \\
Online shop with delivery & 1.8 \\
Hard to tell & 6.1 \\
No answer & 4.2 \\
\hline
\end{tabular}

Source: own research

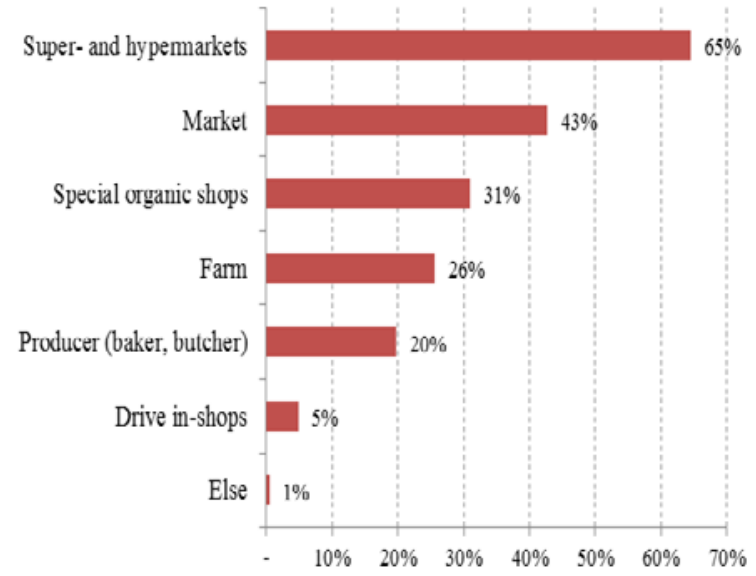

Figure 5. Sales location of organic products in France Source: Agence Bio - CSA (2011)

The willingness to pay from 0 to $10 \%$ reached high positive values of the factor variable (2.31). It means that the most attractive premium for organic products should not exceed $10 \%$. This conclusion is related mainly to alcoholic beverages, snacks, cereals, processed milk products (Tab. 4).

Majority of respondents expressed their willingness to pay a premium for organic products not exceeding $30 \%$ of the conventional product price. 
Table 4. The share of respondents willing to pay a premium for organic products, Dnepropetrovsk region (\%)

\begin{tabular}{|c|c|c|c|c|c|c|c|c|c|c|c|c|c|c|c|}
\hline $\begin{array}{l}\text { What a premium } \\
\text { you are ready to } \\
\text { pay for organic } \\
\text { products }(\%)\end{array}$ & 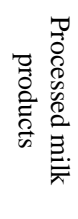 & $\begin{array}{l}\vec{T} \\
\vec{E}\end{array}$ & 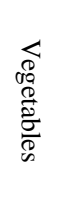 & $\begin{array}{l}3 \\
\stackrel{2}{\dddot{2}}\end{array}$ & $\stackrel{T}{\mathscr{n}}$ & $\begin{array}{l}\text { Th } \\
\text { ga } \\
\text { da } \\
c a\end{array}$ & 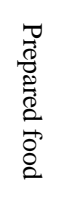 & 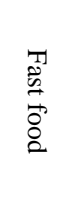 & $\begin{array}{l}\stackrel{0}{0} \\
\frac{0}{0} \\
\frac{\tilde{D}}{\omega}\end{array}$ & 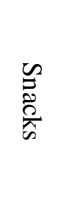 & 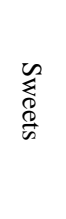 & 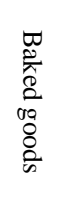 & 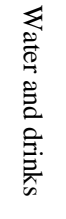 & 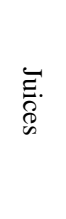 & 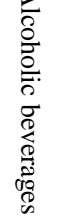 \\
\hline 0 & 15.2 & 16.0 & 15.8 & 14.6 & 15.8 & 17.6 & 22.1 & 21.4 & 19.3 & 29.8 & 19.9 & 18.2 & 19.8 & 17.9 & 22.4 \\
\hline $1-10$ & 27.3 & 22.4 & 23.2 & 21.1 & 22.1 & 26.6 & 25.2 & 25.6 & 27.6 & 28.8 & 23.8 & 25.4 & 26.8 & 25.2 & 30.5 \\
\hline $11-20$ & 20.0 & 16.9 & 14.5 & 16.1 & 16.0 & 13.3 & 13.4 & 16.4 & 14.1 & 9.9 & 17.6 & 15.3 & 15.8 & 18.4 & 12.1 \\
\hline 21-30 & 8.9 & 12.1 & 14.4 & 11.5 & 8.9 & 8.7 & 7.6 & 6.4 & 6.0 & 4.8 & 8.1 & 7.2 & 6.2 & 7.9 & 6.5 \\
\hline $31-40$ & 3.6 & 4.9 & 4.6 & 6.8 & 5.5 & 5.1 & 4.0 & 4.5 & 4.0 & 2.8 & 3.5 & 5.1 & 3.3 & 3.4 & 2.4 \\
\hline $41-50$ & 4.1 & 4.4 & 5.1 & 5.1 & 5.9 & 4.2 & 3.8 & 4.1 & 5.1 & 2.4 & 3.4 & 3.6 & 3.2 & 3.6 & 4.1 \\
\hline 51-60 & 5.2 & 3.9 & 3.9 & 4.7 & 4.4 & 3.9 & 4.2 & 4.0 & 3.9 & 2.6 & 4.1 & 4.8 & 3.6 & 3.6 & 2.5 \\
\hline $61-70$ & 1.9 & 2.4 & 2.7 & 2.6 & 1.5 & 2.4 & 2.6 & 1.9 & 1.9 & 0.7 & 1.3 & 1.3 & 1.8 & 1.6 & 1.6 \\
\hline 71-80 & 1.6 & 1.5 & 0.9 & 3.3 & 2.6 & 1.9 & 0.6 & 0.9 & 1.1 & 0.6 & 1.1 & 1.3 & 0.9 & 1.3 & 1.1 \\
\hline $81-90$ & 1.5 & 0.5 & 0.6 & 1.6 & 1.1 & 1.2 & 1.3 & 1.1 & 0.8 & 0.5 & 0.6 & 0.8 & 1.1 & 0.8 & 0.7 \\
\hline $91-100$ & 1.1 & 0.8 & 1.4 & 1.3 & 1.1 & 0.9 & 0.8 & 0.4 & 1.1 & 0.7 & 0.8 & 1.2 & 0.8 & 0.8 & 0.8 \\
\hline $101-200$ & 0.1 & 0.6 & 0.2 & 0.5 & 0.9 & 0.2 & 0.5 & 0.2 & 0.7 & 0.5 & 0.4 & 0.6 & 0.7 & 0.9 & 0.5 \\
\hline More than 200 & 0.9 & 0.9 & 1.2 & 0.8 & 0.9 & 0.9 & 0.8 & 0.7 & 1.2 & 1.1 & 0.8 & 0.8 & 0.7 & 0.9 & 1.3 \\
\hline No answer & 8.5 & 12.7 & 11.6 & 10.0 & 13.3 & 13.1 & 13.1 & 12.5 & 13.3 & 14.9 & 14.6 & 14.4 & 15.3 & 13.5 & 13.6 \\
\hline
\end{tabular}

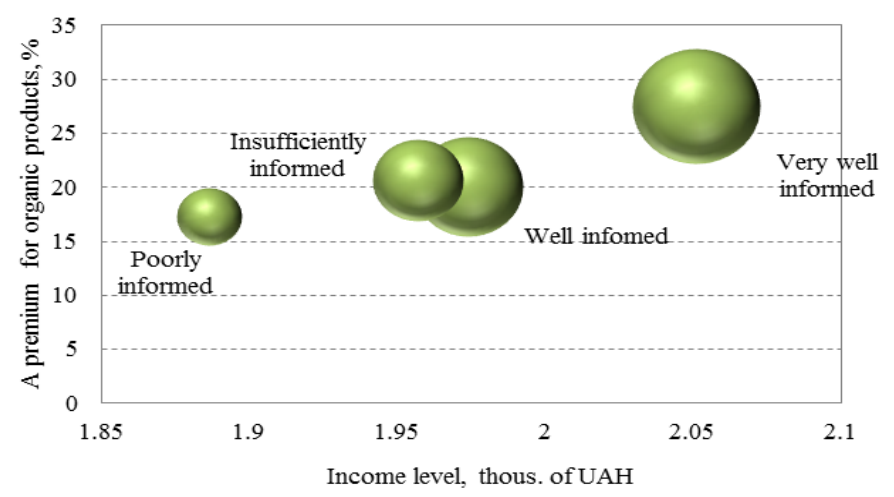

Figure 6. Willingness to pay a premium for organic products and income per family member of respondents in Dnepropetrovsk region.

Note: A size of bubble represents the share of respondents. Source: own research

\section{CONCLUSION}

We found that awareness of organic products of the respondent in Dnepropetrovsk region was related with their willingness to pay a premium for organic products. Willingness to pay a premium for organic products increased with income per family member (Fig. 6). There was a relation between education level of respondents and the level of awareness. Farming centres formed in educational establishments in Ukraine can promote consumers awareness of organic food and consequently, their willingness to pay a premium for such products.

\section{REFERENCES}

AGENCE BIO - CSA (2011). Baromètre de consommation et de perception des produits biologiques en France. Edition 2011, p123.

ARTYSH, V. I. (2006). Management aspects of the production of environmentally friendly products in agriculture of Ukraine. Scientific Journal of Nat. Agrarian Univ. - K. - № 102. - P. 242-247
BERLACH, N. (2010). Analysis of motivational factors in terms of administrative and legal regulation in the development of organic agriculture in Ukraine. Legal Psychology and Pedagogy. - № 2 (8) - P. 186-194. Federation of Organic Movement of Ukraine. (2014) Official site. Available at: $\quad$ http://www.organic.com.ua/uk/news/315-pressconference

LUPENKO, Y. O. 2013 Formation of supply and demand in the market on organic products. Organic Production and Food Security. - Zhytomyr: Polessye, $492 \mathrm{p.}$

LVIVSKI NOVINI, (2012). This year 7 million of organic products will be eaten in Ukraine. Online. Available

at: http://lvivexpres.com/news/2012/11/08/36970

Ministry of Agrarian Policy and Food of Ukraine (2013). The state will provide help to stimulate organic production.

Available at: http://minagro.gov.ua/en/node/7038

MYLOVANOV, Y. V. (2009). Organic agriculture: prospects for Ukraine. Handbook of Ukrainian Farmer: scientific-practical. collection. - P. 257-260. 
SOKOL, L.M. - STEFANOVSKA, T.R - PIDLISNYUK, T.R.(2008) Ecological (Organic agriculture) is a key component of sustainable agriculture. Ecologichna bezpeka .-2008. -Volume 3-4 - P.102-108 (ukr.)

SHUMETOV, V. G. (1999). Factor analysis: Approach with computers, Orel HTU, Orel. - 88p.

Soil Association. Organic market report 2013. Available at: http://www.soilassociation.org/LinkClick.aspx?filetic ket=whbpEnZUd7A=
TCHAIKA T. A. (2011). Status of the market of Ukrainian organic production and its potential. Journal of Ryazansk State Agrotechnical University named P. A. Kostycheva. - 2011. - № 4 (12). - P. 63-67.

YATSENKO, O. M. - ZAVADSKA, Y. S. (2010), Formation of demand on organic products in the agrofood. Ukrainian scientific-practical journal "Innovative Economy" -№ 3 - P. 204-208. 